08

\title{
Влияние отжига при температуре выше температуры солидуса на структуру и гальваномагнитные свойства тонких пленок твердого раствора $\mathrm{Bi}_{92} \mathrm{Sb}_{8}$
}

\author{
(C) В.М. Грабов, Е.В. Демидов, Е.К. Иванова, В.А. Комаров, Н.С. Каблукова, \\ А.Н. Крушельницкий, М.В. Старицын
}

Российский государственный педагогический университет им. А.И. Герцена, 191186 Санкт-Петербург, Россия

I e-mail: demidov_evg@yandex.ru

(Поступило в Редакцию 16 мая 2016 г.)

Исследовано влияние температуры отжига в интервале температур между температурами солидуса и ликвидуса твердого раствора $\mathrm{Bi}_{92} \mathrm{Sb}_{8}$ на структуру, а также гальваномагнитные и термоэлектрические свойства. Показано, что для получения пленок твердого раствора висмут-сурьма с крупноблочной структурой методом термического испарения в вакууме необходимо проведение их отжига при температуре выше температуры солидуса твердого раствора. Установлено, что такие пленки обладают наименьшим удельным сопротивлением, наибольшим относительным магнетосопротивлением и наибольшей подвижностью носителей заряда. При приближении температуры отжига к температуре ликвидуса возрастает вероятность образования в пленке дендритной структуры и появления областей, обогащенных сурьмой, что приводит к возрастанию концентрации носителей заряда и уменьшению удельного сопротивления при уменьшении относительного магнетосопротивления и подвижности носителей заряда.

DOI: 10.21883/JTF.2017.07.44681.1889

\section{Введение}

Гальваномагнитные и термоэлектрические свойства тонких пленок, в частности висмута, определяются совершенством их структуры: количеством дефектов, размерами блоков, их кристаллографической ориентацией. Одним из методов улучшения структуры уже сформированных на подложке пленок является отжиг.

Отжиг пленок висмута, полученных вакуумным напылением на кристаллическую подложку (слюда мусковит), приводит к существенному изменению их структуры и свойств [1-4]. При этом влияние отжига зависит от исходной структуры пленки. Например, для пленок висмута толщиной $0.3 \mu \mathrm{m}$, полученных на подложках из слюды при температурах $350-410 \mathrm{~K}$, отжиг при температуре $520 \mathrm{~K}$ приводит к увеличению размеров блоков в 5-8 раз (до 5-6 $\mathrm{m}$ ). Аналогичный отжиг пленок висмута, полученных при температуре подложки выше $420 \mathrm{~K}$, почти не приводит к изменению размеров блоков. Такое различие влияния отжига обусловлено различной исходной структурой пленок. В обоих случаях структура пленок подобна: ось $C_{3}$ блоков перпендикулярна плоскости подложки, но при температурах подложки $350-410 \mathrm{~K}$ реализуется согласованная кристаллографическая ориентация соседних кристаллитов с антипараллельным направлением осей $C_{2}$ в то время как при температуре подложки выше $420 \mathrm{~K}$ появляются блоки с произвольной ориентацией оси $C_{2}$ в плоскости пленки [1].

Было также установлено [5], что в пленках висмута, легированного теллуром, полученных методом вакуумного напыления на подложки из слюды, увеличение концентрации теллура до 0.1 at.\% приводит к значительному уменьшению размеров кристаллитов и уменьшению влияния отжига на их размер. Аналогичная закономерность наблюдается и для пленок системы висмутсурьма, полученных на подложках из слюды [6]. Например, для пленок $\mathrm{Bi}_{92} \mathrm{Sb}_{8}$ толщиной $0.3 \mu \mathrm{m}$ на слюде, размеры кристаллитов не превышают $1.5 \mu \mathrm{m}$, и заметно не возрастают при отжиге даже при температуре $540 \mathrm{~K}$, близкой к температуре плавления висмута, что, вероятно, обусловлено наличием в структуре пленок атомов сурьмы.

С целью выявления возможности получения на подложках из слюды пленок висмут-сурьма с более совершенной структурой и высокой подвижностью носителей заряда проведено исследование влияния на структуру пленок твердого раствора висмут-сурьма отжига при температуре выше температуры солидуса $\left(T_{\text {sol }}\right)$ материала пленок, а также исследованы их гальваномагнитные и термоэлектрические свойства.

\section{Эксперимент}

Исследование проведено на примере сплава висмутсурьма с содержанием сурьмы 8 at.\% $\left(\mathrm{Bi}_{82} \mathrm{Sb}_{8}\right)$.

Пленки висмут-сурьма были получены методом дискретного термического испарения в высоком вакууме $\left(10^{-5}\right.$ Torr $)$ с конденсацией на подложку из слюды мусковит при фиксированной температуре подложки $400 \mathrm{~K}$. Использование дискретного испарения обеспечивает однородность состава пленки. Отжиг проводился без нарушения вакуума в течение $60 \mathrm{~min}$ при фиксирован- 
ных температурах в интервале между температурами солидуса и ликвидуса выбранного состава. Согласно диаграмме состояний бинарного сплава висмут-сурьма, температура солидуса для $\mathrm{Bi}_{92} \mathrm{Sb}_{8}$ составляет $553 \mathrm{~K}$, а ликвидуса $588 \mathrm{~K}$ [7]. Для сравнения исследовались пленки, полученные без отжига и с отжигом при температуре $540 \mathrm{~K}$, которая ниже температуры плавления кристаллов висмута.

Исследование структуры пленок проводилось с использованием атомно-силового микроскопа Solver P47-Pro в полуконтактном режиме на воздухе с использованием методики, предложенной в $[8,9]$. Структура пленок также исследовалась с использованием рентгеновского дифрактометра ДРОН-7 в медном $K_{\alpha}$-излучении и растрового электронного микроскопа EVO-40 фирмы Carl Zeiss, оснащенного дифракционной приставкой HKL Nordlys Nano.

Исследование гальваномагнитных и термоэлектрических свойств проводилось по классической методике в интервале температур $77-300 \mathrm{~K}$ и магнитном поле до $0.65 \mathrm{~T}$.

\section{Структура пленок}

Исследование структуры поверхности пленок методом атомно-силовой микроскопии (АСМ) показало, что все исследованные пленки $\mathrm{Bi}_{92} \mathrm{Sb}_{8}$ на слюде, полученные без отжига и с отжигом при $540 \mathrm{~K}$, характеризуются текстурой, в которой ось третьего порядка $C_{3}$ во всех блоках перпендикулярна плоскости подложки, а оси $C_{2}$ соседних блоков имеют в большинстве случаев согласованную ориентацию, при которой они антипараллельны. Об этом свидетельствуют четко выраженные треугольные фигуры роста на поверхности пленки и их взаимная ориентация в соседних блоках. АСМ изображение поверхности такой пленки приведено на рис. 1, $a$.

Отжиг при температуре выше температуры солидуса приводит к существенному изменению структуры поверхности пленки. В результате отжига при $553 \mathrm{~K}$ на поверхности пленки исчезли фигуры роста правильной геометрической формы, характерные для роста из паровой фазы, а образовались области неправильной формы, имеющие плоскую поверхность с малой шероховатостью (рис. $1, b)$.

Наблюдаемые изменения структуры поверхности пленок при малой их толщине указывают на то, что отжиг при температуре выше температуры солидуса сплава приводит к значительному изменению внутренней структуры пленок. Известно, что сплавы висмутсурьма склонны к дендритной ликвации, поэтому в пленке при температуре выше температуры солидуса может происходить образование областей с повышенной концентрацией сурьмы.

Рентгеноструктурные исследования этих же пленок не выявили столь существенных различий. Дифрактограммы, полученные от поверхности пленок $\mathrm{Bi}_{92} \mathrm{Sb}_{8}$ с
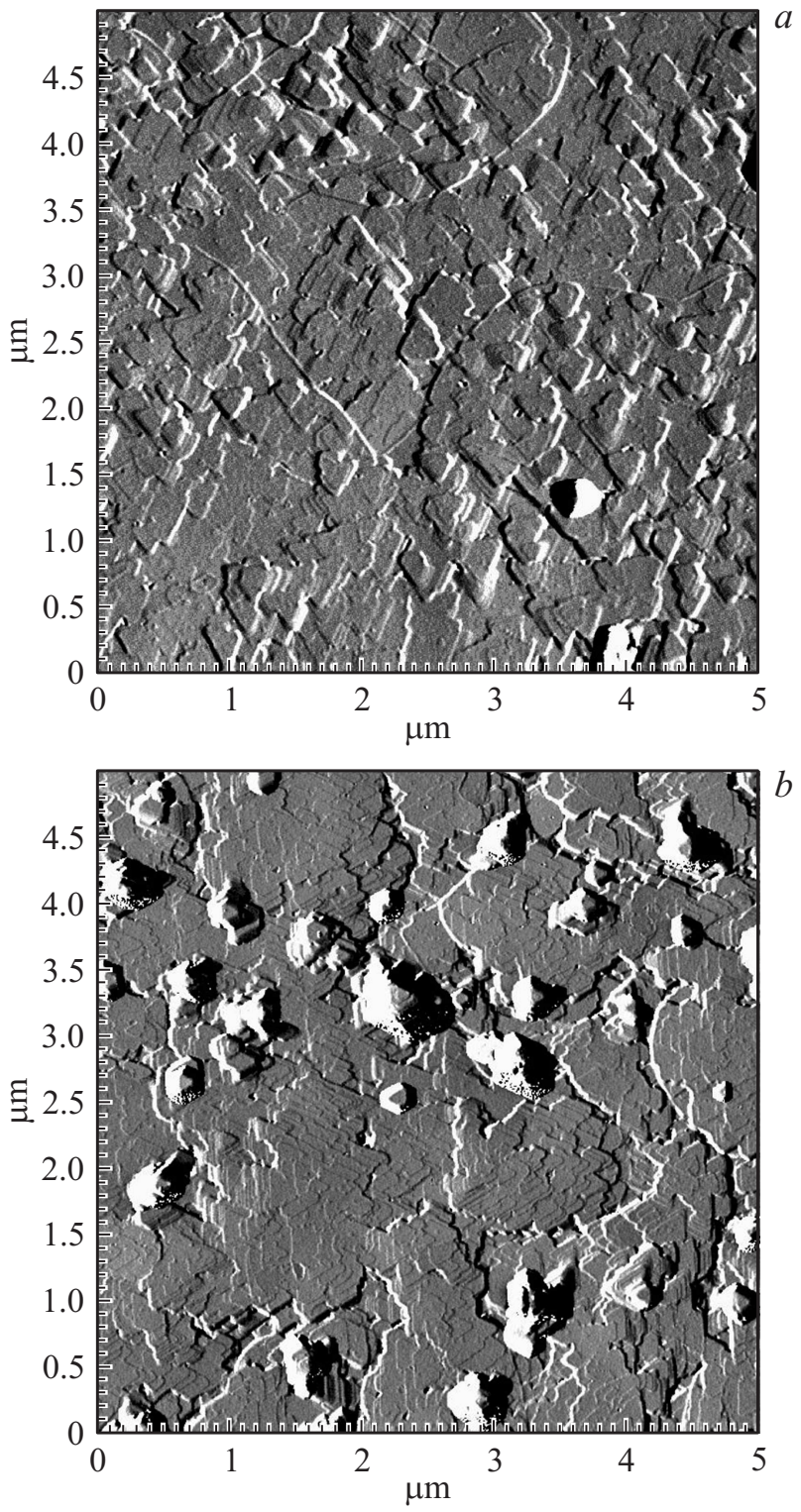

Рис. 1. АСМ изображения поверхности пленок $\mathrm{Bi}_{92} \mathrm{Sb}_{8}$ толщиной $0.3 \mu \mathrm{m}$ на слюде, полученных при различной температуре отжига: $a-540, b-553 \mathrm{~K}$.

учетом максимумов подложки (слюды), соответствуют дифрактограмме от тригональной плоскости монокристалла $\mathrm{Bi}_{92} \mathrm{Sb}_{8}$, что указывает на ориентацию оси $C_{3}$ всех кристаллитов перпендикулярно плоскости подложки [3]. Однако следует отметить ухудшение разрешения дифракционных максимумов пятого порядка (0015) $K_{\alpha 1^{-}}$ и $K_{\alpha 2}$-линий излучения меди на дифрактограмме пленки при повышении температуры отжига (рис. 2). Причиной этого, вероятнее всего, является увеличившаяся неоднородность распределения сурьмы в пленке.

Использование метода дифракции отраженных электронов дало возможность получить карты распределения кристаллографических ориентаций в пленках $\mathrm{Bi}_{92} \mathrm{Sb}_{8}$, полученных при различной температуре отжига. Это 


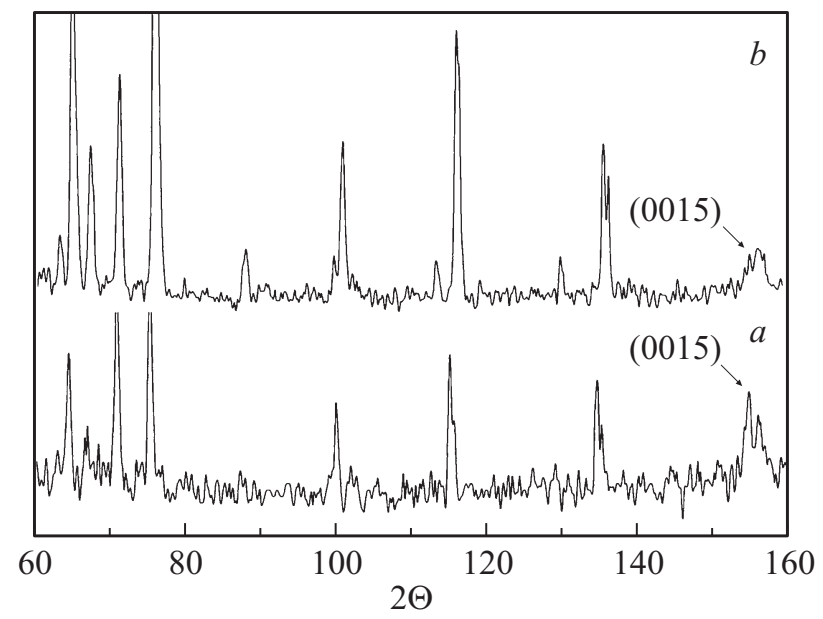

Рис. 2. Дифрактограммы от плоскости пленок $\mathrm{Bi}_{92} \mathrm{Sb}_{8}$ толщиной $0.3 \mu \mathrm{m}$ на слюде, полученных с отжигом $540(a)$ и $588 \mathrm{~K}(b)$.

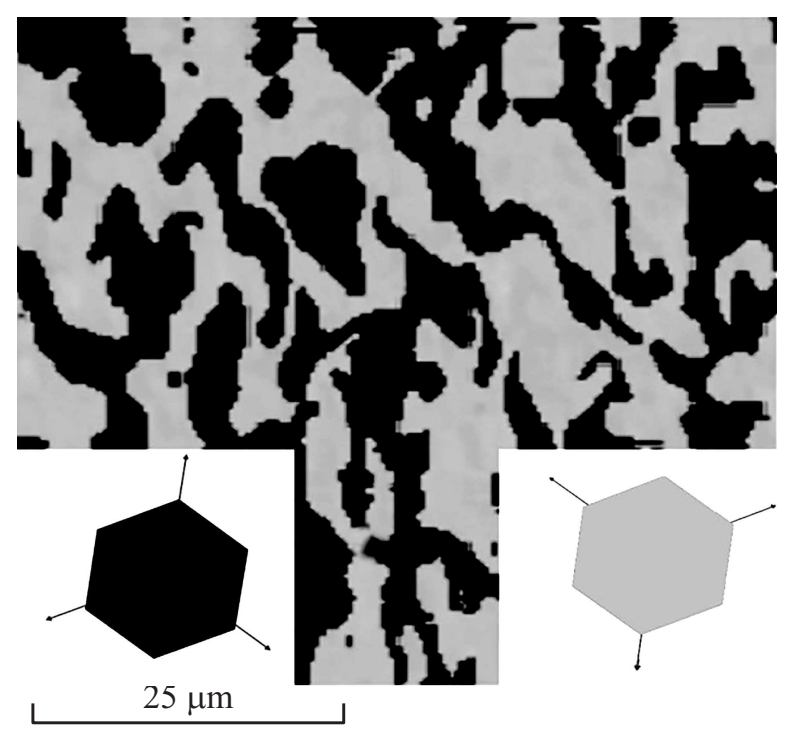

Рис. 3. Карта распределения кристаллографических ориентаций пленок $\mathrm{Bi}_{92} \mathrm{Sb}_{8}$, полученных при температуре подложки $400 \mathrm{~K}$ и температуре отжига $578 \mathrm{~K}$.

позволило визуализировать блочную структуру пленок, определить взаимную кристаллографическую ориентацию блоков и их размер.

На рис. 3 приведен пример карты распределения кристаллографических ориентаций в пленке $\mathrm{Bi}_{92} \mathrm{Sb}_{8}$. Отчетливо видно наличие только двух согласованных ориентаций. На вставках рис. 3 показана кристаллографическая ориентация для „светлых“ и „темных“ блоков. Такую ориентацию соседних блоков можно представить как поворот кристалла со сменой направлений осей $C_{3}$ и $C_{2}$ на противоположные, что согласуется с результатом, полученным методом АСМ по взаимной ориентации фигур роста на поверхности пленок. На АСМ изображениях эти блоки отличаются противоположной ориентацией треугольных фигур роста.

На основании картографирования методом дифракции отраженных электронов определены средние размеры блоков в пленках $\mathrm{Bi}_{92} \mathrm{Sb}_{8}$ с отжигом при различной температуре. Полученные результаты представлены на рис. 4.

Как следует из полученных результатов, отжиг при температуре выше температуры солидуса приводит к значительному увеличению размеров блоков. Их величина становится примерно равной размерам блоков в пленке висмута такой же толщины на слюде после отжига при температуре $520 \mathrm{~K}$ [1].

Для анализа зависимости размеров блоков $(D)$ от температуры отжига $\left(T_{a n n}\right)$ была использована закономерность, полученная в работе [1]:

$$
D\left(T_{a n n}\right)=\left[D_{0}^{2}+A \exp \left(-\frac{Q}{R T_{a n n}}\right)\right]^{\frac{1}{2}},
$$

где $D_{0}-$ средний размер блоков в пленке до отжига, $A-$ коэффициент, зависящий от времени отжига, $R-$ универсальная газовая постоянная, $Q-$ энергия активации отжига в расчете на $1 \mathrm{~mol}$. Коэффициент $A$, зависящий от времени отжига, принимался постоянным, так как время отжига для всех пленок было одинаковым.

Полученные экспериментальные результаты были представлены в виде зависимости

$$
\ln \left(\left(\frac{D(T)}{D_{0}}\right)^{2}-1\right)=f\left(\frac{1}{T_{a n n}}\right)
$$

которая соответствует прямой линии (рис. 5, вставка). На основе данной закономерности определена энергия активации процесса отжига $Q=181 \pm 29 \mathrm{~kJ} / \mathrm{mol}$, величина которой совпадает с энергией парообразования висмута $180 \mathrm{~kJ} / \mathrm{mol}$ [10].

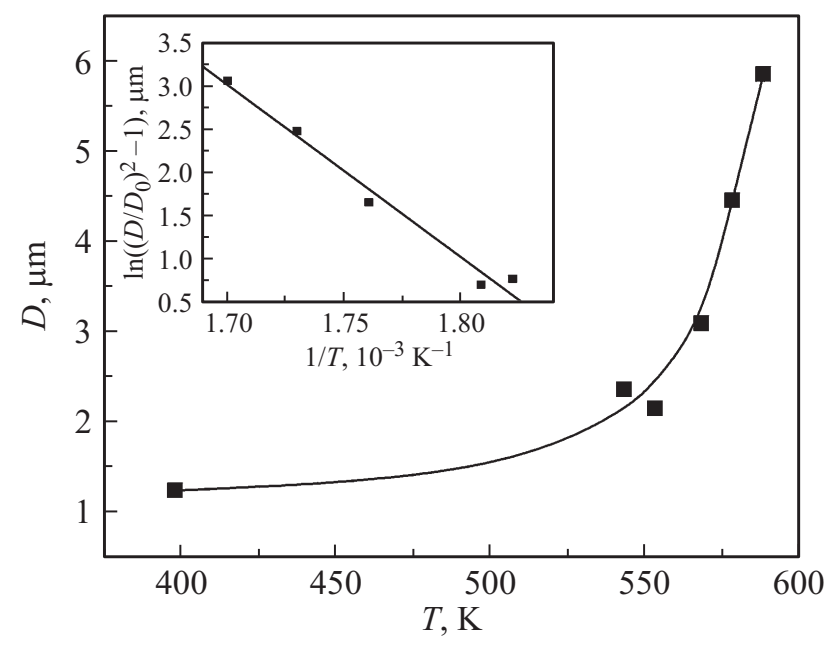

Рис. 4. Зависимость размера блоков в пленках $\mathrm{Bi}_{92} \mathrm{Sb}_{8}$ толщиной $0.3 \mu \mathrm{m}$ на слюде от температуры отжига. 

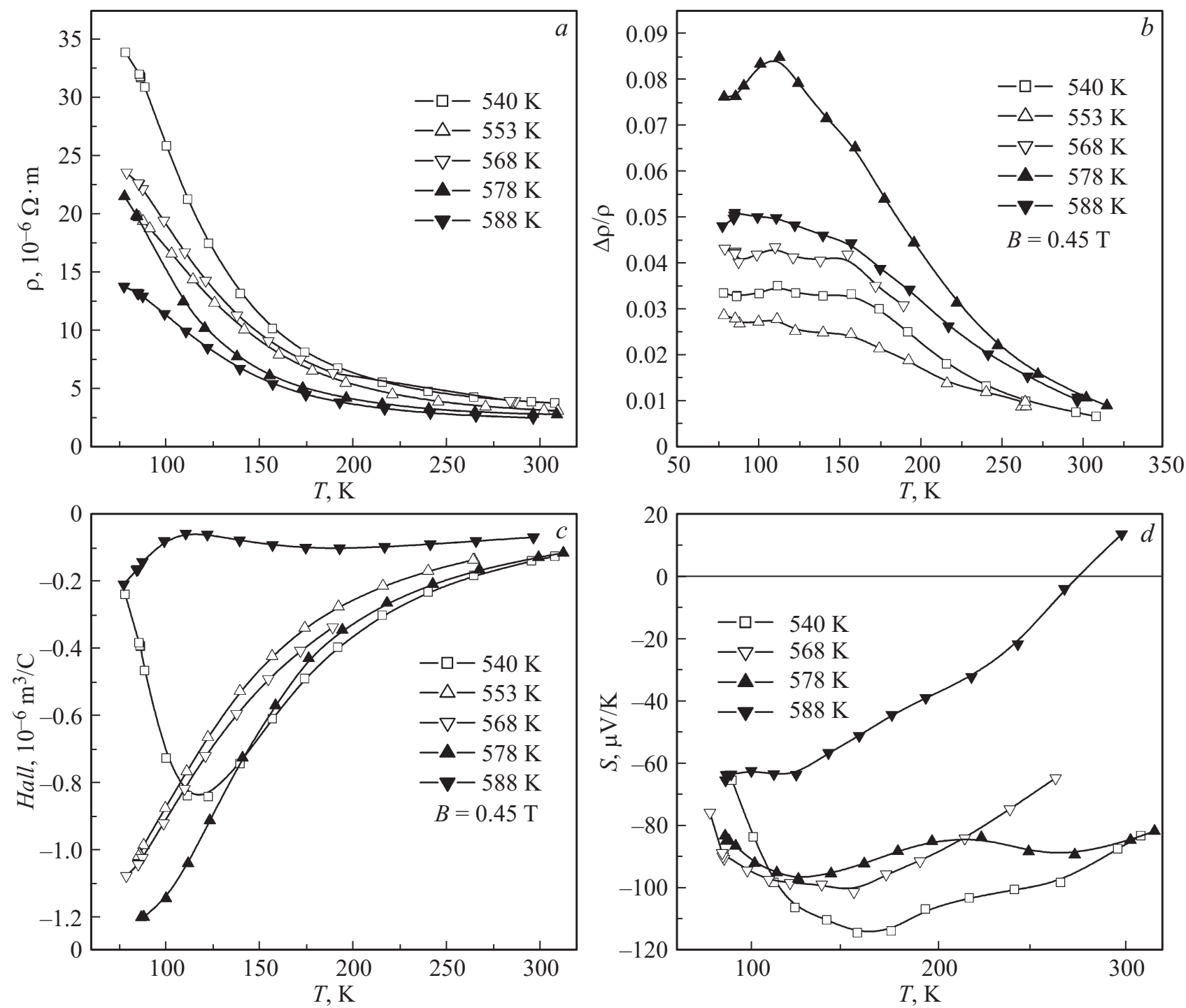

Рис. 5. Зависимость удельного сопротивления (a), магнетосопротивления $(b)$, коэффициента Холла $(c)$ и коэффициента Зеебека $(d)$ от температуры пленок $\mathrm{Bi}_{92} \mathrm{Sb}_{8}$ толщиной $0.3 \mu \mathrm{m}$, полученных с отжигом при различной температуре.

Полученное значение энергии активации отжига значительно больше величины $109 \mathrm{~kJ} / \mathrm{mol}$ [1], которая характерна для отжига пленок висмута на слюде при взаимно согласованной ориентации осей $C_{2}$. Фактором, препятствующим рекристаллизации при отжиге пленок $\mathrm{Bi}_{92} \mathrm{Sb}_{8}$, вероятнее всего, является наличие в твердом растворе двух типов атомов. Это подтверждается и результатами работы по исследованию пленок висмута, легированного теллуром [5], в которой указывается на уменьшение размеров блоков при увеличении концентрации легирующей примеси (до 0.1 ат.\%).

Таким образом, исследование структуры пленок показало, что отжиг при температуре выше температуры солидуса сплава позволяет получать пленки висмутсурьма, состоящие из блоков, размеры которых в несколько раз больше, чем в пленках, полученных с отжигом при температуре ниже температуры солидуса, и приближаются к величине блоков в пленках висмута такой же толщины.

Приближение температуры отжига пленки к температуре ликвидуса сплава приводит к возрастанию дендритной структуры пленки с возможным выделением тонких прослоек, сильно обогащенных сурьмой.

\section{Гальваномагнитные и термоэлектрические свойства пленок}

Для изготовленных с отжигом при различной температуре пленок $\mathrm{Bi}_{92} \mathrm{Sb}_{8}$ толщиной $0.3 \mu \mathrm{m}$ на слюде исследованы температурные зависимости удельного сопротивления, относительного магнетосопротивления, коэффициента Холла и коэффициента Зеебека в интервале температур $77-300 \mathrm{~K}$ и магнитном поле до $0.65 \mathrm{~T}$. Полученные результаты приведены на рис. 5. 
Удельное сопротивление всех исследованных пленок $\mathrm{Bi}_{92} \mathrm{Sb}_{8}$ возрастает при понижении температуры (рис. 5,a) и заметно уменьшается при повышении температуры отжига во всем исследованном интервале температур. Уменьшение удельного сопротивления пленок висмут-сурьма при повышении температуры отжига происходит неравномерно.

Так, при повышении температуры отжига от 540 до $553 \mathrm{~K}$ удельное сопротивление при $77 \mathrm{~K}$ уменьшается в 1.4 раза, а увеличение температуры отжига от 553 до $578 \mathrm{~K}$ почти не изменяет его. Дальнейшее повышение температуры отжига до $588 \mathrm{~K}$ приводит к новому резкому уменьшению сопротивления примерно в 1.5 раза. Сопоставление с результатами исследования структуры пленок показывает, что первая ступень изменения сопротивления (540-553 K) соответствует значительному увеличению размеров кристаллитов вследствие отжига пленок. Вторая ступень соответствует возникновению и развитию дендритной структуры пленок.

Как следует из рис. 5, $b$, повышение температуры отжига приводит к увеличению магнетосопротивления пленок $\mathrm{Bi}_{92} \mathrm{Sb}_{8}$ примерно в 2 раза при $77 \mathrm{~K}$, что также подтверждает соответствие наблюдаемых изменений явлений переноса с изменениями структуры пленок под воздействием отжига при температурах выше температуры солидуса сплавов висмут-сурьма.

Результаты исследования коэффициентов Холла и Зеебека находятся в согласии с выводами, сформулированными при анализе результатов исследования удельного сопротивления и магнетосопротивления. Эффекты Холла и Зеебека - разностные эффекты. Изменение величины коэффициентов Холла и Зеебека отражает изменение не только величины, но и соотношения вкладов электронов и дырок.

Отжиг пленок при температуре выше температуры солидуса приводит к исчезновению минимума на температурной зависимости коэффициента Холла, характерного для пленок $\mathrm{Bi}_{92} \mathrm{Sb}_{8}$ на слюде (рис. 5,c). Этот минимум, вероятно, смещается в область температуры ниже $77 \mathrm{~K}$.

Наиболее существенные изменения температурной зависимости коэффициента Холла соответствуют пленке, полученной с отжигом при 588 К. Коэффициент Холла имеет малое отрицательное значение, слабо изменяющееся с понижением температуры, и только при температуре ниже $120 \mathrm{~K}$ начинает возрастать по абсолютной величине.

Аналогичные изменения происходят и в температурной зависимости коэффициента Зеебека (рис. 5, d). Наибольшее отличие имеет температурная зависимость коэффициента Зеебека для пленки, полученной с отжигом при $588 \mathrm{~K}$, которая в исследованной серии пленок имеет наименьшее отрицательное значение и даже переходит в область положительных значений при температурах выше $250 \mathrm{~K}$.

Такие изменения коэффициентов Холла и Зеебека пленок $\mathrm{Bi}_{92} \mathrm{Sb}_{8}$ подтверждают сделанные выше выводы о существенном влиянии изменения структуры пленок

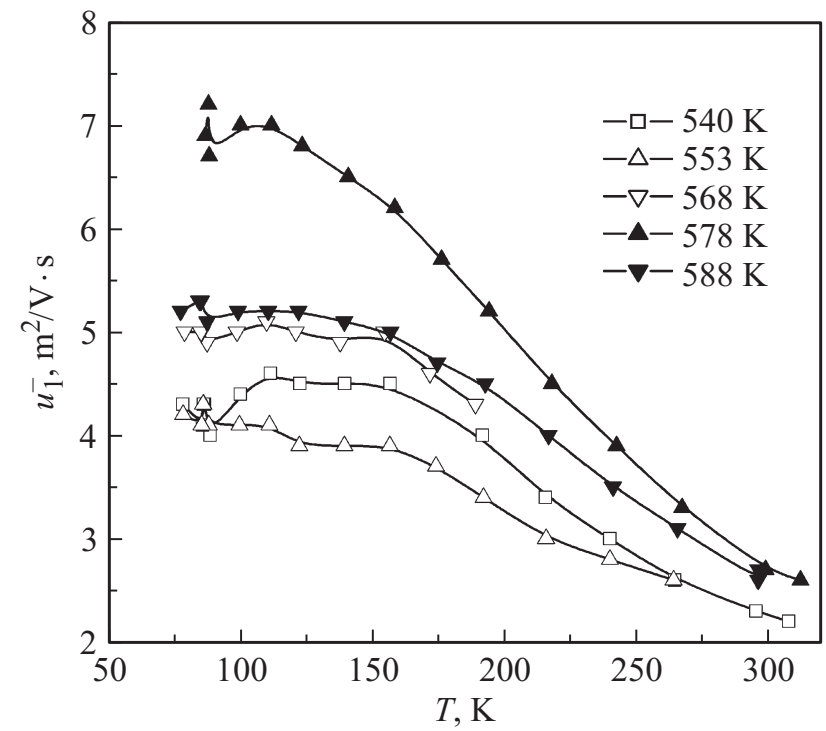

Рис. 6. Зависимости подвижности электронов от температуры в пленках $\mathrm{Bi}_{92} \mathrm{Sb}_{8}$ на слюде мусковит при различной температуре отжига.

под воздействием отжига при температурах выше температуры содидуса, появления дендритности с возможным выделением прослоек, обогащенных сурьмой, в пленках, полученных с отжигом при температуре 588 К. Коэффициент Зеебека монокристалла сурьмы имеет положительный знак и при $300 \mathrm{~K}$ его значение близко значению коэффициента Зеебека пленки $\mathrm{Bi}_{92} \mathrm{Sb}_{8}$, полученной с отжигом при температуре $588 \mathrm{~K}$, поэтому весьма вероятно преобладание вклада в эффект Зеебека пленки прослоек, обогащенных сурьмой. При понижении температуры коэффициент Зеебека сурьмы уменьшается, поэтому в пленке начинает преобладать вклад областей, богатых висмутом, и коэффициент Зеебека переходит в область отрицательных значений. Малое значение коэффициента Холла в пленках $\mathrm{Bi}_{92} \mathrm{Sb}_{8}$, полученных с отжигом при $588 \mathrm{~K}$, также является следствием большой дендритности этих пленок.

Результаты исследования удельного сопротивления, магнетосопротивления и коэффициента Холла пленок $\mathrm{Bi}_{2} \mathrm{Sb}_{8}$ дали возможность рассчитать подвижность и концентрацию носителей заряда в этих пленках. С учетом кристаллографической ориентации пленок, измеряемые в них коэффициенты переноса $\left(\rho_{11}, R_{12,3}, \rho_{11,33}\right)$ можно представить через параметры носителей заряда в виде следующих выражений [3]:

$$
\begin{gathered}
\frac{1}{\rho_{11}}=\sigma_{11}=e\left[\frac{1}{2} n\left(u_{1}^{-}+u_{2}^{-}\right)+p u_{1}^{+}\right] \\
R_{12,3}=e \rho_{11}^{2}\left[p\left(u_{1}^{+}\right)^{2}-n u_{1}^{-} u_{2}^{-}\right] \\
\rho_{11,33}=\rho_{11}^{2} e\left[\frac{1}{2} n u_{1}^{-} u_{2}^{-}\left(u_{1}^{-}+u_{2}^{-}\right)+p\left(u_{1}^{+}\right)^{3}\right]-\sigma_{11} R_{12,3}^{2} .
\end{gathered}
$$




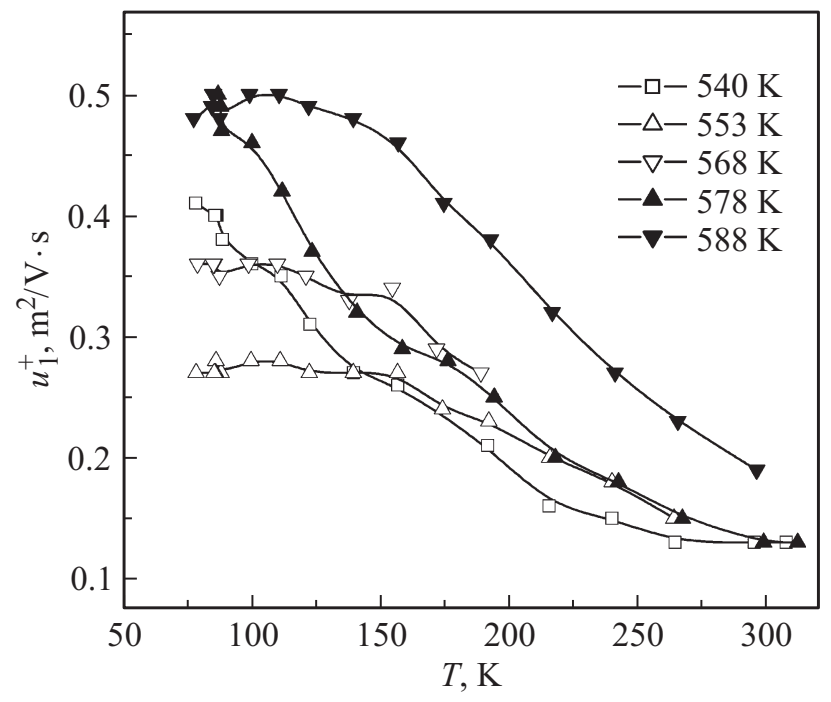

Pис. 7. Зависимости подвижности дырок от температуры в пленках $\mathrm{Bi}_{92} \mathrm{Sb}_{8}$ на слюде мусковит при различной температуре отжига.

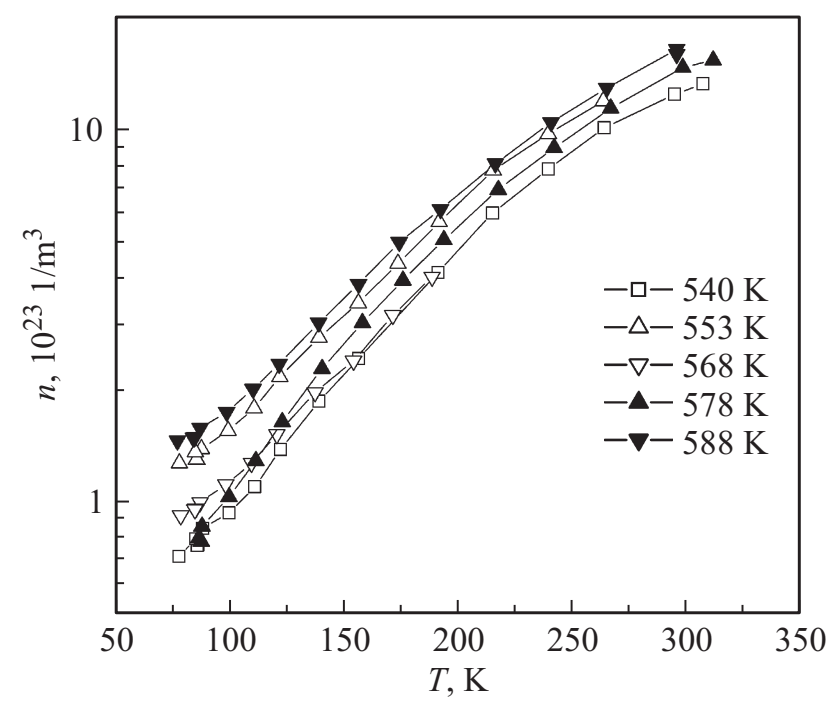

Рис. 8. Зависимости концентрации носителей заряда в пленках $\mathrm{Bi}_{92} \mathrm{Sb}_{8}$ на слюде мусковит при различной температуре отжига.

В выражениях (3)-(5) e - модуль заряда электрона, $u$ - подвижность носителей заряда. Задача решалась в приближении равенства концентраций электронов $(n)$ и дырок $(p)$, а также при условии сохранения соотношения между компонентами подвижности электронов $u_{1}^{-}$и $u_{2}^{-}$, соответствующего монокристаллу. В этом случае задача сводится к решению системы трех уравнений с тремя неизвестными. На рис. 6-8 приведены полученные результаты.

Подвижность электронов и дырок увеличивается при повышении температуры отжига. Максимальная подвижность электронов соответствует пленке, полученной с отжигом при $578 \mathrm{~K}$. Отжиг при $588 \mathrm{~K}$ приводит к пре- имущественному возрастанию подвижности дырок в исследованном интервале температур. Этой же пленке соответствует наибольшая концентрация носителей заряда (рис. 8), что согласуется с появлением областей, сильно обогащенных сурьмой, с более высокой концентрацией носителей заряда.

\section{Заключение}

Для получения пленок твердого раствора висмутсурьма методом вакуумного осаждения на подложках из слюды, имеющих крупноблочную структуру с ориентацией оси $C_{3}$ перпендикулярно подложке, оптимальным является проведение отжига при температуре выше температуры солидуса. Приближение температуры отжига пленки к температуре ликвидуса сплава приводит к возрастанию дендритной структуры пленки с возможным выделением тонких прослоек, сильно обогащенных сурьмой.

Изменение гальваномагнитных и термоэлектрических свойств пленок $\mathrm{Bi}_{92} \mathrm{Sb}_{8}$ при повышении температуры отжига выше температуры солидуса обусловлено увеличением размеров кристаллитов. В процессе отжига пленок $\mathrm{Bi}_{92} \mathrm{Sb}_{8}$ на слюде в вакууме при температуре в интервале $\left(T_{\text {sol }}-\left(T_{\text {sol }}+20\right)\right) \mathrm{K}$ происходит рекристаллизация, сопровождаемая ростом размером кристаллитов, что обеспечивает уменьшение дефектности структуры пленок и повышение подвижности носителей заряда. При приближении температуры отжига к температуре ликвидуса коэффициента Холла и Зеебека по модулю принимают наименьшие значения при наибольших значениях концентрации носителей заряда, что связано с формированием дендритной структуры и возможным появлением прослоек, обогащенных сурьмой, в структуре этих пленок. Наибольшие по модулю значения коэффициента Зеебека достигаются в пленках с отжигом при $540 \mathrm{~K}$, характеризующихся наименьшими размерами блоков. Наибольшая подвижность электронов соответствует пленке, полученной с отжигом при $578 \mathrm{~K}$, которая характеризуется бо́льшими размерами блоков при меньшей развитости дендритной структуры по сравнению с пленками, полученными с отжигом при $588 \mathrm{~K}$.

Работа выполнена при финансовой поддержке РФФИ (грант № 16-32-00313) и Минобрнауки России в рамках базовой части государственного задания № 2014/376 на выполнение государственных работ в сфере научной деятельности (проект № 59).

\section{Список литературы}

[1] Грабов В.М., Демидов Е.В., Комаров В.А. // ФТТ. 2010. Т. 52. Вып. 6.С. 1219-1222.

[2] Грабов В.М., Демидов Е.В., Комаров В.А. // Поверхность. Рентгеновские, синхротронные и нейтронные исследования. 2011. № 2. С. 81-85. 
[3] Грабов В.М., Комаров В.А., Демидов Е.В. Гальваномагнитные и термоэлектрические явления в тонких пленках висмута и сплавов висмут-сурьма. СПб.: РГПУ им. А.И. Герцена, 2011. $124 \mathrm{c}$.

[4] Грабов В.М., Демидов Е.В., Комаров В.А., Матвеев Д.Ю., Николаева А.А., Маркушевс Д., Константинов Е.В., Константинова Е.Е. // ФТП 2014. Т. 48. Вып. 5. С. $648-$ 653.

[5] Комаров В.А., Матвеев Д.Ю., Худякова И.И., Крушельницкий А.Н. // Известия РГПУ им. А.И. Герцена. 2012. T. 147. C. $50-63$.

[6] Комаров В.А., Демидов Е.В., Каблукова Н.С., Христич E.E., Маркушевс Д. // Термоэлектрики и их применения: Доклады XIII Межгосударственного семинара. СПб.: ФТИ 2013. С. 352-357.

[7] Лякишев Н.П. Диаграммы состояния двойных металлических систем. Справочник в 3 т. Т. 1. М.: Машиностроение 1996. $992 \mathrm{c}$.

[8] Грабов В.М., Демидов Е.В., Комаров В.А. // ФТТ. 2008. Т. 50. Вып. 7. С. 1312-1316.

[9] Грабов В.М., Демидов Е.В., Комаров В.А., Климантов М.M. // ФТТ. 2009. Т. 51. Вып. 4. С. 800-802.

[10] W.E. Thokneycroft. Antimony and bismuth // A Textbook of Inorganic chemistry. V. 6. Pt 5 / Ed. by Friend J.N. London: Charles Griffin \& Co., Ltd. 1936. 249 p. 